\title{
Sequencing Deliberative Moments
}

\author{
Robert E. Goodin \\ Philosophy Program, Research School of Social Sciences, Building 09, Australian National \\ University, Australia. \\ E-mail: goodinb@coombs.anu.edu.au
}

I offer a model of 'distributed' (or 'delegated') deliberation — with different agents playing different deliberative roles - as an alternative to the 'unitary actor' model of deliberation. It might be 'good enough', deliberatively, for the component deliberative virtues to be on display sequentially, over the course of this staged deliberation involving various component parts, rather than continuously and simultaneously present as they would be in the case of a unitary deliberating actor. Acta Politica (2005) 40, 182-196. doi:10.1057/palgrave.ap.5500098

Keywords: deliberative democracy; deliberative quality; distributive deliberation; sequenced deliberation; deliberative Schumpeterianism

\section{Introduction}

Philosophers write at length about the political, moral and epistemic virtues of deliberating together in an 'ideal communication situation'. ${ }^{1}$ Whether and how those ideals can be implemented in the real world is as philosophers say often in dismissive tones - an 'empirical question'. But philosophers must always remember that 'ought implies can'. Moralizing can only sensibly occur within the limits of what empirically can and cannot be done.

With the 'coming of age of deliberative democracy' (Bohman, 1998), philosophers have begun to appreciate the full force of that point, adapting their normative prescriptions accordingly. Jürgen Habermas still thinks that 'justified and binding decisions about policies and laws demand... that deliberation and decision making take place face to face', but he now acknowledges that 'at the level of direct and simple interactions, not all citizens can join in the shared exercise of such a practice' (1996, 170). So he now advocates 'two-track deliberation', in which 'a discursively structured public sphere' feeds into 'representative bodies for deliberation and decision-making' (1996, 182).

Here I explore further the possibilities of dividing up the deliberative task, assigning different portions of it to different agents, and holding them to different deliberative standards accordingly. That model is empirically interesting, because it is the only way interpersonal deliberation can, in 
practice, proceed among a large number of agents (Goodin, 2003, chapter 7). Normatively, that may not be ideal: but the question is just whether some form of that might be tolerably acceptable.

\section{Setting Discursive Standards}

As regards standards for what counts as 'good' discourse and deliberation, there seems to be an impressively broad scholarly consensus. Just compare the criteria proposed by: the Oxford-Berkeley philosopher of language, Paul Grice; the team of international relations specialists led by Knud Midgaard; and the team of comparative politics experts led by Jürg Steiner (see similarly Nowell-Smith, 1954, 81-82). Table 1 sets their respective criteria of 'good discourse' alongside one another.

Although organized slightly differently, these lists are remarkably convergent. Those are not the product of any direct cross-fertilization: none of these teams make any explicit reference to one another's work, and they all draw their inspiration from different sources (Steiner from Habermas, the other two from Austin). Of course, deeper down there are common roots. Nevertheless, it is striking that independent observers as varied as these come up with such similar criteria of what constitutes 'good discursive practice'. Before we seize upon this happy news, however, we ought to pause briefly to consider what these are tests of. We need to consider whether, and how, they might properly be used to study genuinely political interactions.

\section{Cooperative games, shared purposes: the unitary deliberator model}

I shall say more about the content of those lists shortly. First, however, I want to point out a deeper, structural feature underlying all these models. All represent discourse - conversation, political interlocution or deliberation as fundamentally a cooperative game, in the technical game-theoretic sense of the term. There is assumed to be no conflict of interest between any of the parties to the game; what is good for one is good for all (or anyway, good for some and not bad for any).

That is most explicit in the case of Grice, who posits a 'Cooperative Principle' as governing all conversation, and from that principle derives his other more specific Maxims of Conversation. However, the fundamentally cooperative nature of discourse is deeply rooted in philosophical analysis of language as a set of conventions (Lewis, 1969). The uses we make of those shared conventions might be anything but cooperative: we might want to use words whose meanings we share to contradict or criticize or insult one another. The point is simply that, in order to do any of that, we even more 
2. Justification of assertions and validity claims - Assertions should be introduced and critically assessed through 'the orderly exchange of information and reasons'....

- Do not say what you believe to be false.

- The tighter the connection between premises and conclusions, the more coherent the justification is and the more useful it will be for deliberation.

- Do not say that for which you lack adequate

3. Relevance evidence.

- Stick (in a reasonable degree) to what

3. Consideration of the common good is relevant to the official purpose and to

3. Relation the addressee.

- Be relevant.

\section{Attentiveness}

- Pay attention to what is said by the other participants.
- [T]here should be a sense of empathy, otherdirectedness or solidarity that causes the participants to consider the well-being of others and of the community at large.

- Someone using self-interest must demonstrate that it is compatible with or contributes to the common good. 
Table 1 Continued

Maxims of conversation

Rules of political interlocution

Indices of deliberative quality

4. Manner

- Avoid obscurity of expression.

5. Respect

4. Respect

- Avoid ambiguity

- Show respect toward the other parti-

- [Participants should] acknowledge the needs and rights of different social groups. cipants.

- [Participants should] respect the demands under discussion, as long as they can intersubjectively be seen as justified.

- Be brief (avoid unnecessary prolixity).

- [Participants should show] respect toward counterarguments raised by opponents that contradict their own conclusions...

- Be orderly.

5. Aim at a rationally motivated consensus

- [A] discourse should at least attempt to reach mutually acceptable compromise solutions...

6. Authenticity, without deception in expressing preferences

- [S]tated preferences should be sincere rather than strategic..

Midgaard et al. $(1973,20)$ and Midgaard Steiner et al. (2004, chapter 3). $(1980,87)$ 
fundamentally want our messages to be meaningful to one another. At that more fundamental level, systems of communication simply have to be, at root, a cooperative game.

One of the above standards of 'good deliberative practice' might follow straightforwardly from that of basic analysis of the conventionality of language itself. That is the principle of veracity: saying only what you genuinely believe to be true. It is crucial that speakers generally respect that rule, in order for the rest of us even to be able to surmise what they mean by the propositions that they are asserting (Lewis, 1969, 194). If they regularly lie, there will be no pattern for us to pick in assigning meaning to their utterances. The rest of the precepts of 'good discursive practice' in Table 1 do not, however, follow directly from the nature of language and communication itself. Instead they derive from the special requirements of special sorts of linguistic encounters: 'purposive conversations' (Grice); ones with an 'official purpose' (Midgaard, 1980); ones aimed at joint resolution of some specific issue (Steiner).

Communication in the real world, of course, is not the purely cooperative game of philosophical imagination but instead a mixed-motive game of strategy. Not all parties to a conversation-cum-deliberation necessarily share the same view of the 'purpose' of the discussion, of 'what it is about'. The topic on the table is typically one of the things up for discussion, not something taken as read from the outset, in formal negotiations as much as in informal conversations. In a political discussion, particularly, the 'definition of the problem' - what is the problem under discussion, and what would count as a solution - is typically something to be discussed, not something fixed prior to discussion. Still, even if there is inevitably a certain amount of gaming over those issues, strategic actors are often obliged to take the 'official' topic as given, pro tem, and at least to pretend that their interventions constitute contributions toward its resolution.

Certainly the formal processes of political deliberation are organized 'as if' the group was essentially a single agent with a unified purpose. Rules of parliamentary procedure are, first and foremost, Rules of Order (Robert, 1951). They set out procedures by which the group might systematically set about deliberating over a complex issue. Rules of parliamentary procedure prescribe for a group deliberation what the rules of logic prescribe for an individual (Oakeshott, 1975, 43-46, 173-180). Take one topic at a time; decompose it into its component parts; decide on each of those components in a logical sequence; stick to the point (Robert, 1951, 180-182; Jefferson, 1988, 274). In a way, those are familiar pieties that constitute the 'dignified' fiction upon which deliberative institutions are based. Parliamentarians pay periodic tribute to them. Their obeisance is often shallow. Rules of order and parliamentary proceedings typically constitute the 'institutional framework' within which political games are played out; and here as in commerce, 'players' are anything 
but 'gentlemen' (Coleman, 1973; Goodin, 2000). Still, it is less the reality of parliamentary discourse that concerns me at this point than the fiction. The rules of parliamentary procedure invite us to see a legislature - ideally, at least - as a unified deliberative agent. Those rules suggest a legislature ought to operate according to the same standards of logic, order, coherence, etc., as ought a single natural individual deliberating on the same matter.

\section{Distributed Deliberation}

In developing an alternative model of how group deliberation might proceed among a group not unified by a common 'purpose', let us reflect upon how legislatures actually operate. Recall with General Robert $(1951,19,211)$ that 'the work of Congress is enormous and is mostly done by standing committees...' Indeed, 'it is usual in deliberative assemblies' quite generally 'to have all preliminary work in the preparation of matter for their action done by means of committees'. 2 Those committees are creatures of the parent assembly, deliberating on issues assigned to them by the parent assembly. They report back to the parent assembly, and their reports then form the basis for subsequent deliberations of the parent assembly; indeed, 'in nine cases out of ten its action decides that of the assembly' (Robert, 1951, 220).

Not only does the parent assembly delegate certain elements of its deliberative task to these other subgroups. Those delegated deliberations furthermore proceed in slightly different ways than do deliberations in the parent assembly. General Robert $(1951,211)$ begins by saying that the rules of procedure governing committees are broadly the same as those governing the parent assembly; but he then immediately proceeds to itemize a litany of important differences. For example:

- Members can speak as often as they like on a motion in committee, but only once (or with special dispensation twice) on the floor.

- Any member can move to reconsider past action in committee, whereas only a member who voted on the winning side can bring a motion to reconsider on the floor.

- In committee, the chairperson takes an active part in the deliberations, whereas in the legislative chamber itself the chair's role is more purely procedural.

To some extent those differences can be explained by the sheer fact of size of the respective groups. Being smaller, committees can afford to dispense with some of the formality that is required to manage business in an orderly fashion in larger assemblies (Robert, 1951, 208, 213). But to some extent the differences in procedure reflect the fact that the committee and the parent assembly are performing different tasks. 
The committee is engaged in drafting (and redrafting) proposals; in giving detailed consideration to proposals line-by-line; in fact-finding and in framing appropriate responses to the facts found (Robert, 1951, 279-283). This is creative, cooperative work. The parent assembly, in contrast, is more in the business of disposing of proposals, affirmatively or negatively. ${ }^{3}$ Discourse in the former venue is aimed more at refining proposals. In the latter venue, it is aimed more at rationalizing acceptance or rejection. These are all familiar facts about legislative assemblies. My proposal here is that they be generalized to deliberation tout court. My suggestion is that it is always possible, and with large groups almost always desirable, to divide up the deliberative task in such ways.

Different parts of the deliberative task can then be assigned to different subsets of the larger group. The deliberations of these sub-units serve as background and inputs into the deliberations of the larger group with overall deliberative responsibility. Furthermore, just as with legislative committees, the terms on which those sub-units conduct their delegated deliberative business can (and probably ordinarily should) differ somewhat from the terms on which the larger group conducts its own deliberations. In short, the procedures and deliberative standards - to which we should hold deliberative agents in such a system of 'distributed' or 'delegated' deliberation are not necessarily the same as those to which we would rightly hold a single, unified deliberative agent. In a world of delegated deliberation, where different parts of the deliberative task are divided up and shared among various different agents, appropriate behavior within each component part of that distributed deliberation is not necessarily the same as appropriate behavior where one body is performing the whole deliberative task on its own.

\section{Different steps, different deliberative expectations}

Consider, then, four different steps in the operation of representative democracy and what might be considered as constituting 'good deliberative practice' within each of them. The exercise is intended to be illustrative rather than exhaustive. There is much more that goes on within representative democracy that ought also be held up to ethical scrutiny; and there are various other ethical standards to be brought to bear, besides just the deliberative one. Still, four stages will suffice to illustrate the point. And for those purposes, it also suffices simply take the 'indices of deliberative quality' developed by Steenbergen et al. (2002) as our evaluative criteria. Having gotten the point onto the table by reference to stages and standards of those familiar sorts, we can then begin to ponder how to broaden it to other stages (deliberation in civil society or the administrative process, for example) or other standards (of rhetoric, for example). 
Representative democracy might be envisaged as proceeding in the following four stages (Birch, 1964). First, let us suppose, there is the 'caucus room' deliberation, where all the MPs of a single party get together to formulate their own program. Second, let us suppose, there is the 'parliamentary debate', when MPs from all parties publicly present arguments for their preferred position and against other positions. Third, let us suppose, there is an 'election campaign', in which parliamentary candidates compete for office based on the policy positions their parties have taken. Fourth, let us suppose, there is 'post-election arguing and bargaining', in which party leaders negotiate policy deals with one another based on the number of representatives they elect. As I say, this is a highly stylized characterization of a much messier political reality; and it is in no way exhaustive of all alternative possibilities. Still, it will do for the purposes. What we ought to naturally expect is that each of those 'stages of the deliberative process' will display different virtues, judged by the Indicators of Deliberative Quality. Table 2 reproduces those Indicators and foreshadows the conclusions of the following remarks as to where in the deliberative process each of those deliberative virtues is most likely to be found.

The caucus room is first and foremost a place for candor. Members can speak freely, knowing that what is said in the caucus room stays in the caucus room. There, deliberations can achieve 'authenticity, without deception' (Indicator 6) in ways that elsewhere in the process they cannot. Of course, that desideratum is not necessarily met perfectly even in the caucus room. Even within a single party, there are differences of opinion, factional fights and hence motives for dissembling and deceiving one another. Still, it seems reasonable to expect less of that there than elsewhere in the overall deliberative process. And of course 'authenticity' is not the only deliberative virtue on display in the caucus room. Insofar as the party is trying to develop a position that can be defended in open debate to the public at large, that position must be capable of being backed by argument (Indicator 2), ideally in terms of the common good (Indicator 3). ${ }^{4}$ And of course internally, all the other deliberative desiderata are met: participation is open, at least to everyone who is a member of the caucus (Indicator 1); if their votes are to be won, respect must be shown (Indicator 4), albeit again only to members of the caucus; and the aim of the discussion is to produce a rationally motivated consensus (Indicator 5), at least among members of the caucus.

Hence, in saying that 'authenticity' is the principal deliberative virtue on display in the caucus room, I do not mean to imply that either that it is completely on display there or that none of the other deliberative virtues are on display there to any extent. Authenticity is simply the principal virtue of the caucus deliberation, and the caucus is the principal place in the deliberative process where it is found. 
as they can

\begin{tabular}{|c|c|c|}
\hline $\begin{array}{l}\text { Caucus } \\
\text { room }\end{array}$ & $\begin{array}{c}\text { Parliamentary } \\
\text { debate }\end{array}$ & $\begin{array}{l}\text { Election } \\
\text { campaign }\end{array}$ \\
\hline
\end{tabular}


The parliamentary chamber is first and foremost a place to 'put one's case'. Each party sets out the most coherent and persuasive justification it can, for its preferred position. Like barristers arguing a brief, MPs do their best to set out their arguments in an orderly, logical fashion (Indicator 2). Insofar as counterarguments of their opponents threaten to undermine their own case, they respectfully register those arguments and attempt to refute them (Indicator 4c). But in parliamentary debate, no one seriously expects to change any other MP's mind. 'It is the business of an opposition to oppose' (Lindsay, 1935, 47). The various parties are merely 'making their pitch' to the media (lobby correspondents in the old days, television cameras nowadays), and through them to the electorate at large (Lindsay, 1935, 42; Mansbridge, 1988, 64).

Once again, parliamentary debates do not always completely realize this ideal: they merely display those deliberative ideals more than most other stages of the overall deliberative process. And parliamentary debates do display other deliberative virtues, to some extent: (at least ostensible) concern for the common good and rationally motivated consensus and authenticity (Indicators $3,4 a, b, 5,6)$, in anticipation of the need to sell one's case to the electorate; and open participation in debates, at least for all Members of Parliament themselves (Indicator 1). So once again in saying that conjuring up 'rational justifications' is the principal deliberative virtue on display in parliamentary debates, I do not mean to imply that either that it is completely on display there or all other deliberative virtues are totally absent.

The election campaign is the point in the deliberative process where 'participation' is most 'open' to everyone (Indicator 1). Partly in consequence of that, it is also the place where considerations of the 'common good' are most likely to come to the fore (Indicator 3$){ }^{6}$

Of course, the participation in question here is discursive, not just electoral. Many qualified electors fail to vote, and many more affected parties fail to speak. The criterion is couched in terms of mere possibility ('every competent individual' being 'free to take part in the discourse', rather than necessarily actually doing so). Still, there are strict limits on even the sheer possibility of every member of a large electorate having his/her voice heard by all others who are supposed to be party to that same discourse (Goodin, 2003, chapter 7). The most we can realistically expect is that citizens talk to one another, who talk to still others in turn, and that in this way everyone in the community is connected directly or indirectly to everyone else in the discourse (Lindsay, 1935, 38-39).

Similarly, there is no guarantee that discussions spread across a broad public will necessarily focus attention on what is in the common good of that whole public. Still, when parties are trying to appeal to the public as a whole they must at least pretend that their plan is good for the public at large, as well as for their own supporters (Indicator 3b). Evidence suggests that voters vote on 
the basis of what is good for the country as a whole rather than of what is good for them personally (Kinder and Kiewiet, 1981; Kiewiet, 1983; Rohrschneider, 1988). Insofar as they do (or, rather, insofar as parties perceive that they do), it makes good strategic sense for parties to orient their appeals in that way. And insofar as voters are oriented toward the common good in this way, they will orient their own conversations surrounding the election accordingly.

Other deliberative desiderata may well be less well satisfied by election campaigns. Public debate during an election campaign will be a pale shadow of the logically reasoned arguments of parliamentary debates (Indicator 2). ${ }^{7}$ Parliamentary procedure requires MPs to behave as if 'it is not the man, but the measure, that is subject of debate' (Robert, 1951, Section 43, 180); election campaigns are bound by no such rule and are characterized, if anything, by the opposite tendency. In divisive election campaigns, respect for opposing groups, their interests and their arguments (Indicator 4) is also less likely. In an election, the aim is to secure the numbers, not to build a unanimous consensus (Indicator 5). And in an election, strategic maneuvering (contra Indicator 6) is a fact of life, for parties and voters alike. So while election campaigns might display two key deliberative virtues (openness and concern for the common good), they often fall far short on other deliberative dimensions.

Finally, once the election is over, parties come to the bargaining table. Sometimes bargaining is required to form government itself, if no single party commands a workable majority in the legislature. Sometimes arguing and bargaining is required between the different chambers of a bicameral legislature, where different parties control different chambers. Sometimes arguing and bargaining is required between chambers or between factions within the governing party, insofar as they differ over their preferred form legislation should take.

At the bargaining table, the deliberative virtue most on display is 'respect for demands' (Indicator 4b). Bargainers come to the table with settled preferences and firm conclusions. They are not trying to change one another's minds through the force of better arguments. They are not driven by any empathetic desire to help others further their ends. Bargainers acknowledge the 'rights and needs of other groups' (Indicator 4a), if only because they respect the bargaining power of those groups. Bargainers seek 'a mutually acceptable compromise' (Indicator 5) — not so much a 'rationally motivated consensus' as simply a solution. Bargainers merely want to 'do a deal'. Insofar as bargainers are making at least partly conflicting demands (and bargaining would not be required unless they were), each bargainer is attempting to maximize satisfaction of her demands with minimal sacrifice of other things she also demands. All this bargaining purely occurs in terms of demands, with minimal reference to reasons. Of course, no bargaining game is purely a matter of completely conflicting demands. There is always some scope for reciprocal 
concession and reasoned argument in consensus-building, as bargainers try to persuade one another that some solution really is good for both of them and not just for the speaker alone.

\section{Evaluating Sequenced Deliberation}

The preceding argument concerns 'what to expect', not 'what is good'. Let us concede from the start that the 'ideal speech situation' would be best. The very best deliberation, let us suppose, would indeed be a cooperative game among all players in which all the deliberative virtues would be simultaneously and continuously on display. My point is simply that politics is not like that, at least not in the sorts of representative democracies of the sort that now predominate. But while we cannot seriously expect all the deliberative virtues to be constantly on display at every step of the decision process in a representative democracy, we can realistically expect that different deliberative virtues might be on display at different steps of the process.

The question then is whether that can ever be 'good enough', from the point of view of the deliberative ideal. Of course, it is inevitably going to be less good than having all the deliberative virtues simultaneously and continuously on display. But is it better to have those virtues on display sequentially, rather than not at all? I presume the answer must surely be, 'It depends'. Firstly, it depends presumably on having all of the deliberative virtues on display at some point or another in the decision process. Secondly, it presumably depends on the deliberative virtues coming in the right combinations and the right order. There are presumably interactions between different deliberative virtues, and across stages of the deliberative process, which must be taken into account in sequencing the deliberative virtues. Different ways of arranging our political affairs have different implications for the sequencing of deliberative virtues. The particular way of sequencing deliberation within representative democracy that I have been discussing is just one among many, albeit presumably a common one.

What I have been describing is a model of political deliberation where parties propose and electors dispose. Different parties work out their positions behind closed doors, making the deliberative virtue of 'authenticity' possible there. They set out 'reasoned arguments' for their positions in parliamentary debates, governed by rules promoting deliberative virtues of that sort. Those arguments are then put to the 'maximally expansive' deliberative body, the public at large, at an election where the premium is on deliberatively virtuous 'common-good' talk. Once voters have electorally determined the distribution of power in parliament, party leaders convene a probably only semi-public session to cut deals - 'mutually acceptable compromises', based on deliberatively virtuous 
respect for the 'demands' ('rights and needs' — and power) of each respective group.

This model might be dubbed 'deliberative Schumpeterianism'. In the classical Schumpeterian model, the role of parties is to develop coherent policy packages, which they then offer to the electorate. In the 'deliberative Schumpeterian' alternative, the role of parties is to develop coherent policy arguments, which they then offer to the electorate. Those arguments then 'frame' the subsequent debate among the public. ${ }^{8}$ Parties are not the only groups that can serve this policy-development function. Voluntary associations and even interest groups can do likewise (Lindsay, 1935, 39-40; Mansbridge, 1992). Nor are debates in the legislature the only place where issues can be framed for the public at large: that can happen equally well through deliberative polls, citizens' juries, consensus conferences, the media, or whatever (Fishkin, 1995; Page, 1996; Fung, 2003). Nor, even in representative democracies, need the deliberative process necessarily be sequenced in this particular way. The larger point is simply that a staged deliberative process, with different deliberative virtues on display at different stages, might add up to a 'good enough deliberation'. Although not ideal, that is a realistic ambition, perhaps well worth pursuing in its own right.

\section{References}

Bagehot, W. (1966) The English Constitution, Ithaca, NY: Cornell University Press, originally published 1867.

Bohman, J. (1998) 'The coming of age of deliberative democracy', Journal of Political Philosophy 6: 400-425.

Birch, A.H. (1964) Representative and Responsible Government, London: Allen and Unwin.

Coleman, D.C. (1973) 'Gentlemen and players', Economic History Review 26: 92-116.

Dawes, R.M., van de Kragt, A.J.C. and Orbell, J.M. (1990) 'Cooperation for the Benefit of Us Not Me, or My Conscience', in J. J. Mansbridge (ed.) Beyond Self-Interest, Chicago: University of Chicago Press.

Fishkin, J.S. (1995) The Voice of the People: Public Opinion and Democracy, New Haven: Yale University Press.

Frey, B.S. and Bohnet, I. (1996) 'Cooperation, communication and communitarianism: an experimental approach', Journal of Political Philosophy 4: 323-336.

Fung, A. (2003) 'Recipes for public spheres: eleven institutional design choices and their consequences', Journal of Political Philosophy 11: 338-367.

Goodin, R.E. (2000) 'Institutional gaming', Governance 13: 523-533.

Goodin, R.E. (2003) Reflective Democracy, Oxford: Oxford University Press.

Grice, H.P. (1975) 'Logic and Conversation', in D. Davidson and G. Harman (eds.) The Logic of Grammar, Encino, CA: Dickenson.

Habermas, J. (1996) Between Facts and Norms, Cambridge, MA: MIT Press.

Hobbes, T. (1998) On the Citizen, [De Cive], R. Tuck and M. Silverthorne (eds. and trans.), Cambridge: Cambridge University Press, originally published 1647.

Hofstadter, R. (1969) The Idea of a Party System, Berkeley: University of California Press. 
Jefferson, T. (1988) 'Manual of Parliamentary Practice', in W. S. Howell (ed.) Jefferson's Parliamentary Writings, Princeton, NJ: Princeton University Press, originally published 1801.

Kiewiet, D.R. (1983) Micropolitics and Macroeconomics, Chicago: University of Chicago Press.

Kinder, D.R. and Kiewiet, D.R. (1981) 'Sociotropic politics: the American case', British Journal of Political Science 11: 129-161.

Lewis, D. (1969) Convention, Oxford: Blackwell.

Lindsay, A.D. (1935) The Essentials of Democracy, (2nd edn), Oxford: Oxford University Press.

Mansbridge, J.J. (1988) 'Motivating Deliberation in Congress', in S. B. Thurow (ed.) Constitutionalism in America, New York: University Press of America.

Mansbridge, J.J. (1992) 'A Deliberative Theory of Interest Representation', in M.P. Petracca (ed.) The Politics of Interests, Boulder, Co: Westview.

Midgaard, K. (1980) 'On the Significance of Language and a Richer Concept of Rationality', in L. Lewin and E. Vedung (eds.) Politics as Rational Action, Dordrecht: Reidel.

Nowell-Smith, P.H. (1954) Ethics, Harmondsworth, Mddx: Penguin.

Oakeshott, M. (1975) Of Human Conduct, Oxford: Clarendon Press.

Orbell, J.M., von de Kragt, A.J.C. and Dawes, R.M. (1988) 'Explaining discussion-induced cooperation', Journal of Personality and Social Psychology 54: 811-819.

Page, B.I. (1996) Who Deliberates? Mass Media in Modern Democracy, Chicago: University of Chicago Press.

Robert, H.M. (1951) Robert's Rules of Order, revised edn Chicago: Scott, Foresman, originally published 1876.

Rohrschneider, R. (1988) 'Citizens attitudes toward environmental issues: selfish or selfless?' Comparative Political Studies 21: 347-367.

Steenbergen, M.R., Bächtiger, A., Spörndli, M. and Steiner, J. (2002) 'Measuring deliberation: a discourse quality index', Comparative European Politics 1: 21-48.

\section{Notes}

1 I am grateful to participants at the EUI conference, especially Abdré Bächtiger, Simone Chambers, John Dryzek and Jürg Steiner. Work on this paper was carried out under ARC Discovery Grant DP0342795.

2 James Madison tried to persuade the first Congress 'to determine the outlines of all business in the Committee of the Whole', but was outvoted (Mansbridge, 1988, 66).

3 Notably, when it needs to do more than that, the larger assembly typically 'resolves itself into a committee of the whole', operating according to looser rules to 'allow the freest discussion of the subject' (Robert, 1951, 229, 233).

4 Even if the caucus, like small closed sects in general, may in themselves be insular and unprincipled, the fact that it must sell its proposals to parliament and then the electorate ensures that 'principle of some sort or other be always pretended' (Bolingbroke, as quoted in Hofstadter (1969, 21); cf. Lindsay 1935, 40-41).

5 Which explains the findings in Steenbergen et al. $(2002,40)$ that, in House of Commons debates, 'respect for others' demands' (Indicator $4 \mathrm{~b}$ ) is conspicuously missing.

6 The causal conjecture is based on evidence about how communication increases cooperative play in Prisoner Dilemma games (Orbell et al., 1988; Dawes et al., 1990; Frey and Bohnet, 1996). Note Bagehot's $(1966,152)$ parallel comments on expanding one's horizons through petitions of grievances.

7 The problem is longstanding: 'Votes are cast not on the basis of correct reasoning but on emotional impulse' due to the workings of 'eloquence., whose end . is not truth (except by 
accident) but victory; and its task is not to teach but to persuade' (Hobbes, 1998, chapter 10, section 11). The media 'only repeat the side their purchasers like: the favourable arguments are set out, elaborated, illustrated, the adverse arguments maimed, misstated, confused' (Bagehot, 1966, 153).

8 In roughly the ways Lindsay $(1935,42)$ described: 'Profitable discussion in even the smallest group... needs a chairman to define issues and focus attention on the points where discussion will be profitable. In a healthy democracy the discussions of the representative assembly will ... act as chairman for the multifarious informal discussions of the nation as a whole, and the measure of the successful working of democracy is the extent to which the voting of the ordinary man and woman has been informed by this widely diffused public discussion'. See similarly Bagehot (1966, 152-153). 